\title{
Hydrogen peroxide as a biodegradation stimulator in remediation processes of soils heavily contaminated with petrochemicals
}

\author{
Czesława Rosik-Dulewska ${ }^{1}$, Teresa Krzyśko-Łupicka ${ }^{2 *}$, Tomasz Ciesielczuk ${ }^{3}$, Łukasz Kręcidło ${ }^{2}$ \\ ${ }^{1}$ Institute of Environmental Engineering of the Polish Academy of Sciences, Zabrze, Poland \\ ${ }^{2}$ University of Opole, Department of Biotechnology and Molecular Biology, Kominka Str. 6a, 45-035 Opole, Poland \\ ${ }^{3}$ University of Opole, Department of Land Protection, Oleska Str 22, 45-052 Opole, Poland \\ "Corresponding author: e-mail: teresak@uni.opole.pl
}

\begin{abstract}
The soil contaminated with petroleum products must be excluded from the crops and treated to reclamation processes. Natural processes of decomposition of hydrocarbon compounds go very slow, so it is necessary to use bioaugumentation or stimulation in order to accelerate the return of the soil to high culture. In this study the effect of hydrogen peroxide on the process of cleaning soil strongly contaminated with pertochemicals was investigated. For this purpose, a pot experiment lasting 60 days was carried. The dynamics of changes in the population of filamentous fungi, yeasts and bacteria were examined and also content of aliphatic hydrocarbons (n-alkanes), monoaromatic and polycyclic aromatic hydrocarbons (PAHs). Experimental use of hydrogen peroxide in the process of biodegradation of petroleum compounds assisted in the analyzed soil led to an increase of the number of grampositive bacteria during the test. Stimulation of oil products biodegradation by hydrogen peroxide also increased by $35 \%$ decomposition efficiency of aliphatic hydrocarbons (C8-C40) and about 50\% PAH's in comparison to control samples without hydrogen peroxide. There was no influence of hydrogen peroxide on the content of monoaromatic hydrocarbons (BTEX) with respect to controls, although in the end of experiment, the total concentration decreased by about $50 \%$ compared to the initial content.
\end{abstract}

Keywords: soil, remediation, petrochemicals, hydrogen peroxide.

\section{INTRODUCTION}

Crude oil products (petrochemicals) may transform in the environment as a result of physico-chemical as well as biological processes. Attenuation (natural processes to decrease concentrations of contaminants in soil) consists in degradation of petrochemicals by autochthonic microorganisms which use them as a main source of carbon $^{1,2,3,4}$. The process may take even several hundred years ${ }^{5}$. The final attenuation products are typically carbon dioxide, inorganic substances and biomass.

Biodegradation of soil-contaminating petrochemicals depends on site specific conditions such as physical and chemical properties of soil, concentration and structure of the petrochemical contamination, concentration of biogenic compounds, temperature, oxygen content, humidity, soil reaction and activity of the microbial consortia ${ }^{6,7}$.

Soil bioremediation processes may be enhanced by the use of such techniques as bioaugmentation and/or biostimulation $^{5,8}$ with oxygen or/and correcting soil reaction and enrichment with biogenic compounds facilitating the development of autochthonic microbial communities.

The rate of the biodegradation process is to a large extent determined by oxygen delivery to the soil. It can be applied either directly to subsurface (oxygen injection) or in a form of chemical compounds such as ozone or hydrogen peroxide. Due to its properties and decomposing to yield only oxygen and water, hydrogen peroxide is considered environmentally friendly powerful oxidizer, often applied in chemical clean-up processes of soils with pH 3-5 (Fenton reaction) 9, 10, 11, 12. Reactive forms of oxygen radicals may also occur at soil $\mathrm{pH}$ above $5^{\mathbf{1 3}, 14}$.

The aim of this study was to determine the rate of the microbial changes and the biodegradation course in a highly petrochemical contaminated soil treated with hydrogen peroxide.

\section{EXPERIMENTAL}

\section{Material and research methods}

Pot experiment was designed and conducted. Clay soil originating from a petrochemical contaminated site was used for the test. The soil was in a form of fatty black mass of a specific odor, with a high petrochemical content of ca. $17 \mathrm{~g} \mathrm{~kg}^{-1}$ d.m. and $\mathrm{pH} 8$.

Each pot was filled with $1 \mathrm{~kg}$ of contaminated soil. Next hydrogen peroxide $\left(\mathrm{H}_{2} \mathrm{O}_{2}\right)$ was added to the soil in the amount of $1 \mathrm{mg} \mathrm{O}_{2} \mathrm{~g}^{-1}$ d.m $(\mathrm{S}+\mathrm{O})$. Soil with no hydrogen peroxide application was used as control (C). Humidity was maintained at the level of $60 \%$, the mass of the pots was controlled using scales. The pot tests were set up in three replications. Treated soil was incubated in open pots at room temperature of $22^{\circ} \mathrm{C}\left( \pm 2^{\circ} \mathrm{C}\right)$ over a period of 60 days.

To determine the rate of the chemical and microbiological changes, a $10 \mathrm{~g}$ soil sample was collected for analysis from each pot: before the experiment, after 0.25 day (6 hours), after 30 days and after 60 days.

\section{Microbiological methods}

Qualitative and quantitative determination of the microbial populations was carried out using standardized Koch's cultivation method: before the experiment, after 6 hours and after 30 and 60 days of the experiment duration in media typical for specific microorganisms:

- fungi in medium Czapek with glucose ${ }^{15}$

- yeast in medium YPG with chloramphenicol $(0.1 \mathrm{~g}$ $\left.\mathrm{dm}^{-3}\right)^{16,17}$

- bacteria in Nutrient LAB - Agar $^{\mathrm{TM}}$ (BIOCORP)

- actinomycetes in Starch Casein Nitrate Agar (Difco)

- microorganisms capable to grow in medium containing hexadecane as the only source of carbon ${ }^{18}$. 
Bacterial and yeast counts were made after 5 days of experiment set up and 10 days for other investigated microbial populations. The counts of the microorganisms were expressed in $\mathrm{cfu} \mathrm{g}^{-1}$ d.m. ${ }^{2,19}$.

Different bacterial colonies identified in microscope observations were divided into morphological groups using Gram's staining method. Filamentous fungi were determined by their morphological characteristics using selected taxonomic monographs.

\section{Chemical analyses}

- Reaction of the $\mathrm{KCl}$ solution $\left(\mathrm{pH}_{\mathrm{KCl}}\right)$ was determined by potentiometric method using ELPO N-512 pH - meter.

- Dry mass was determined by weight at room temperature.

Samples for chromatographic determinations were weighed and dried at room temperature over anhydrous sodium sulfate ${ }^{20}$.

Investigated compounds were extracted in an automatic fexIKA® extractor (IKA -Werke. Dichloromethane (POCH GC grade) was used for monoaromatic hydrocarbons (BTEX) extraction ${ }^{21}$. Polycyclic aromatic hydrocarbons (PAHs) were extracted using dichloromethane and hexane in proportion 1:9 $(\mathrm{v} / \mathrm{v})^{22}$ while for alkanes - n-hexane (POCH GC grade) was applied. Samples were condensed and purified with activated aluminum oxide before extraction ${ }^{23}$.

Qualitative and quantitative analysis of the produced extracts was carried out by gas chromatography using SHIMADZU GC 17A gas chromatograph coupled to MS-QP5000 mass detector.

Conditions for conducting the chromatographic analysis:

- BTEX - VF5 - ms capillary column 30 m x 0.25 $\mathrm{mm} \times 0.25 \mu \mathrm{m}$; carrier gas $(\mathrm{He})$ flow rate $-1 \mathrm{~cm}^{3}$ per minute, injection port operating temperature $-250^{\circ} \mathrm{C}$, detector temperature $-280^{\circ} \mathrm{C}$; temperature program 30-5 /5/ 170-6; MS detector voltage from 1.2 to $1.4 \mathrm{kV}$

- PAH- VF5 - ms capillary column $30 \mathrm{~m}$ x $0.25 \mathrm{~mm}$ x $0.25 \mu \mathrm{m}$; carrier gas $(\mathrm{He})$ flow rate $-1 \mathrm{~cm}^{3}$ per minute, injection port operating temperature $-300^{\circ} \mathrm{C}$, detector temperature $-310^{\circ} \mathrm{C}$; temperature program $80-8 / 10 /$ 270-12/300-12; MS detector voltage from 1.2 to $1.4 \mathrm{kV}$

- n-aliphatic hydrocarbons - VF1 - ms capillary column $30 \mathrm{~m}$ x $0.53 \mathrm{~mm}$ x $1.50 \mu \mathrm{m}$; carrier gas $(\mathrm{He})$ flow rate $-3 \mathrm{~cm}^{3}$ per minute, injection port operating temperature $-300^{\circ} \mathrm{C}$, detector temperature $-325^{\circ} \mathrm{C}$; temperature program 100-3/12/320-12; MS detector voltage from 1.2 to $1.4 \mathrm{kV}$

The amount of petrochemical substances in soil extracts was determined by integrating cumulative peaks covering the boiling temperature range of $126-522^{\circ} \mathrm{C}$. Aliphatic hydrocarbons of chain length of $\mathrm{C} 8$ (octane) to $\mathrm{C} 40$ (tetracontane) were determined. From the monoaromatic hydrocarbons group, the following were determined: benzene $(\mathrm{B})$, toluene $(\mathrm{T}), \mathrm{m}+\mathrm{p}$-xylene $(\mathrm{m}+\mathrm{p}-\mathrm{x}), \mathrm{o}-\mathrm{xylene}$ (o-x), styrene (Sty) and izopropylobenzene (Izo-pb). In the polycyclic aromatic hydrocarbons group (PAH) the following 16 compunds were deteremined which are recommended for monitoring by the US. EPA: naphtalene (Nap), acenaphtylene (Ayl), acenaphten (Aen), fluorene (Flu), fenantrene (Fen), anthracene (Ant), fluorantene (Fla), pyrene (Pur), benzo[a]anthracene (BaA), chryzene
(Chr), benzo[b,k]fluorantene (BbF, BkF), benzo[a]pyrene (BaP), dibenzo[a,h]anthracene (DhA), indeno[1,2,3-c,d] pyrene $(\mathrm{IcP})$, benzo[g,h,i]perylene $(\mathrm{BgP})$.

\section{RESULTS AND DISCUSSION}

Hydrogen peroxide $\left(\mathrm{H}_{2} \mathrm{O}_{2}\right)$ applied to soil contaminated with petrochemicals (compared to control C) stimulated the growth of prokaryotic microorganisms while slightly inhibited the development of eukaryotic ones which may be attributed to the antagonistic impact. At the same time the number of microorganisms capable of petrochemical compounds degradation in a selective medium with hexadecane as the only source of carbon stayed at constant level (Fig. 1). During the experiment, bacteria dominated (95\%) in the investigated microflora, with the share of grampositive bacteria in the total population on the level of ca. $60 \%$ (Fig. 2).

Microbiological changes in soil with hydrogen peroxide application were accompanied by changes of soil $\mathrm{pH}$ and chemical composition of the analyzed samples. Compared

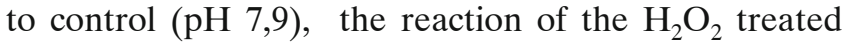
soil has distinctly decreased reaching 6,4 after 60 days of experiment duration (Fig. 3). This indicated production of substances of acid character.

An increase of the effectiveness of petrochemicals removal was observed after hydrogen peroxide application to soil. (Fig. 4). At the incubation phase of the experiment i.e. after 0.25 day, the biodegradation rate was $19 \%$ compared to the initial content, whereas after 60 days it reached $58.7 \%$. Simultaneously however, spontaneous transformations of petrochemicals in control samples were observed during incubation due to autochthonic microorganisms activity. Taking account of this fact, the biodegradation rate was by $21.7 \%$ higher compared to control.

Chemical analysis of petrochemical compounds showed the presence of n-aliphatic, monoaromatic (BTEX) as well as polycyclic aromatic hydrocarbons (PAHs). In the conditions of the experiment, PAHs turned to be the most susceptible to biodegradation and BTEX the least. (Fig. 5).

The effectiveness of the biodegradation process of n-aliphatic hydrocarbons (C8-C40) was by $35 \%$ higher than in control samples (no stimulator applied) with the highest intensity of the process observed between day 30 and 60 of the experiment. A decrease in the content of these hydrocarbons has been observed already after 6 hours since the experiment start up, it especially referred to long-chain hydrocarbons (C17-C40), except for C14 and C16 (Table. 1).

Application of hydrogen peroxide had no influence on the content of monoaromatic hydrocarbons (BTEX) in the contaminated soil. Although upon the completion of the experiment the total concentration of BTEX decreased by ca $50 \%$ compared to the initial values, however after 60 days no differences were observed between the control and the samples with hydrogen peroxide addition which proved no effect of the stimulator on the metabolism of these compounds. The content of basic benzene compounds changed over time however an unambiguous determination of the course of these changes was not possible. A distinct increase of benzene 


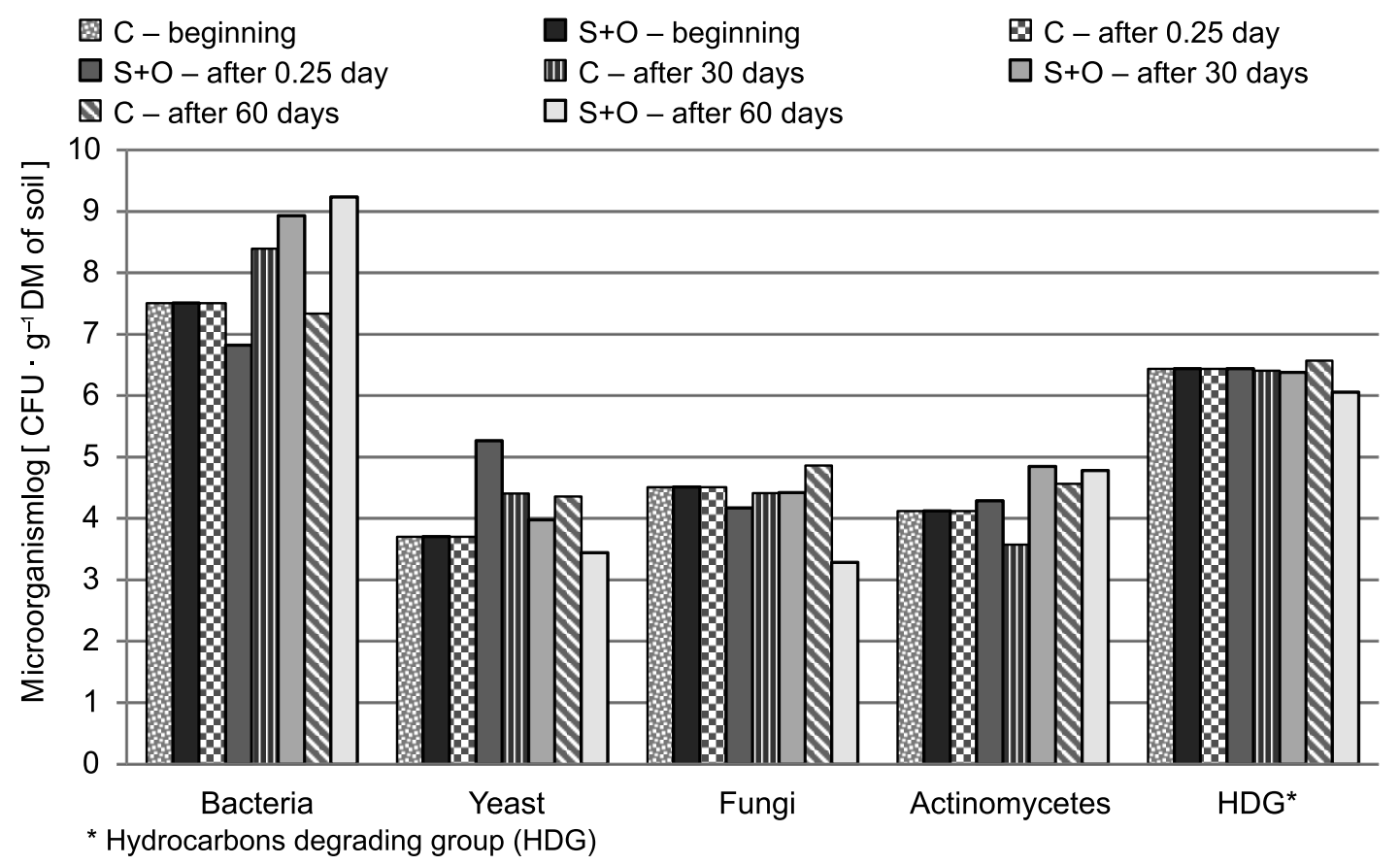

Figure 1. Dynamics of changes of autochthonous microflora number $\left[\log \mathrm{cfu} \cdot \mathrm{g}^{-1} \mathrm{~d}\right.$.m.]. After 0.25 day and 30,60 days of experiment: bacteria, yeast, fungi, actinomycetes, and microorganisms using hexadecane as a source of carbon. (C - control; $\mathrm{S}+\mathrm{O}-$ soil with hydrogen peroxide)

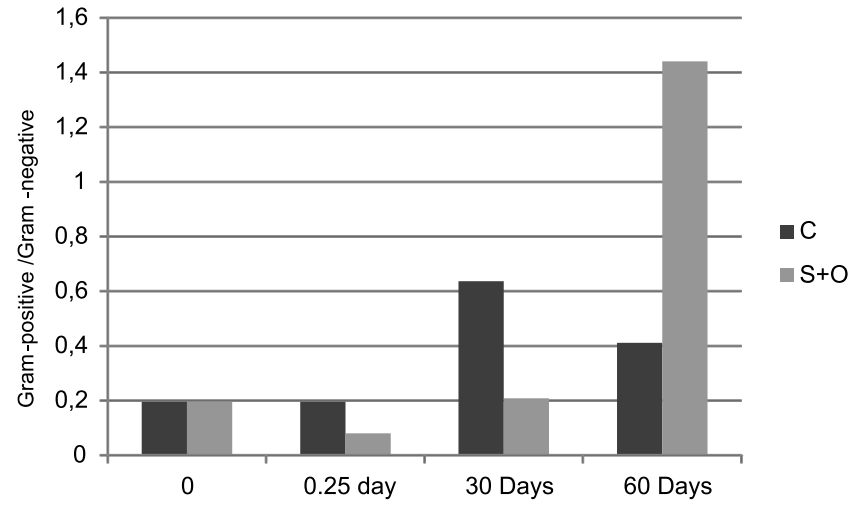

Figure 2. The share of grampositive $(\mathrm{G}+)$ and gramnegative $(\mathrm{G}-)$ bacteria in total population [\%]

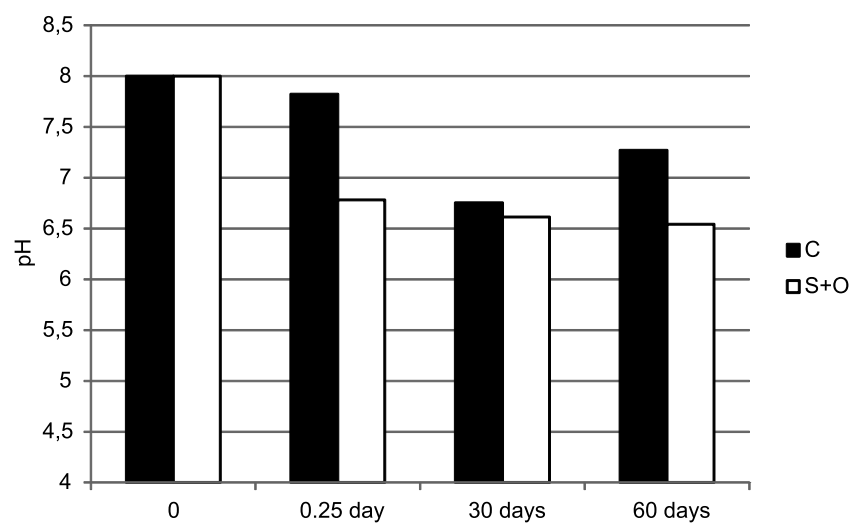

Figure 3. Changes of $\mathrm{pH}$ of soil samples polluted with petrochemicals after use of hydrogen peroxide. $(\mathrm{C}-$ control; $\mathrm{S}+\mathrm{O}$ - soil with $\mathrm{H}_{2} \mathrm{O}_{2}$ )

content was observed until day 30 of the experiment followed by a 10 -fold decrease (Table. 1).

Compared to the initial concentration, the total PAHs content in all investigated samples with $\mathrm{H}_{2} \mathrm{O}_{2}$ addition decreased significantly. The reduction rate was $15 \%$ after

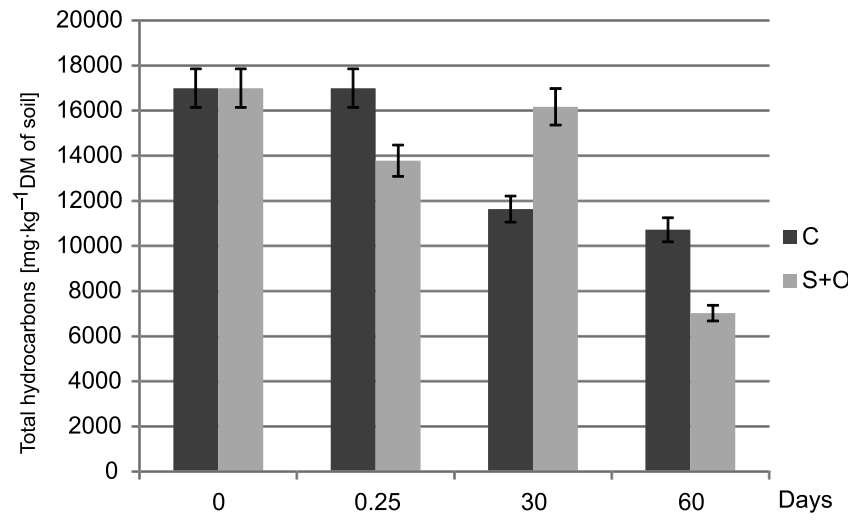

Figure 4. The total content of petrochemicals $\left[\mathrm{mg} \mathrm{kg}^{-1}\right.$ d.m.] in contaminated soil after biodegradation process. (C - control; $\mathrm{S}+\mathrm{O}$ - soil with $\mathrm{H}_{2} \mathrm{O}_{2}$ )

0.25 day and up to $85 \%$ after 60 days. The effectiveness of biodegradation stimulation was by $50 \%$ higher compared to control, although the contents of individual PAHs in $\mathrm{H}_{2} \mathrm{O}_{2}$ stimulated samples changed differently (Table 1.)

Biodegradation of petrochemicals in soil may undergo spontaneously, however to intensify this process different stimulation techniques are applied, especially with the use of environmentally friendly activators such as hydrogen peroxide. In order to use the stimulation techniques in a semi-full or full sale, it is necessary to conduct laboratory tests in order to determine the impact of a given stimulator on the number and activity of the autochthonic microbial populations and thus on the contamination reduction rate.

The experiment showed that the number of prokaryotic microorganisms initially decreased and then increased as a result of hydrogen peroxide stimulation. This effect has been also confirmed by the studies carried by Jung ${ }^{15,16}$. He suggests that small changes in the bacteria number directly after stimulator application result from the use of reactive oxygen forms by hydrocarbons to 


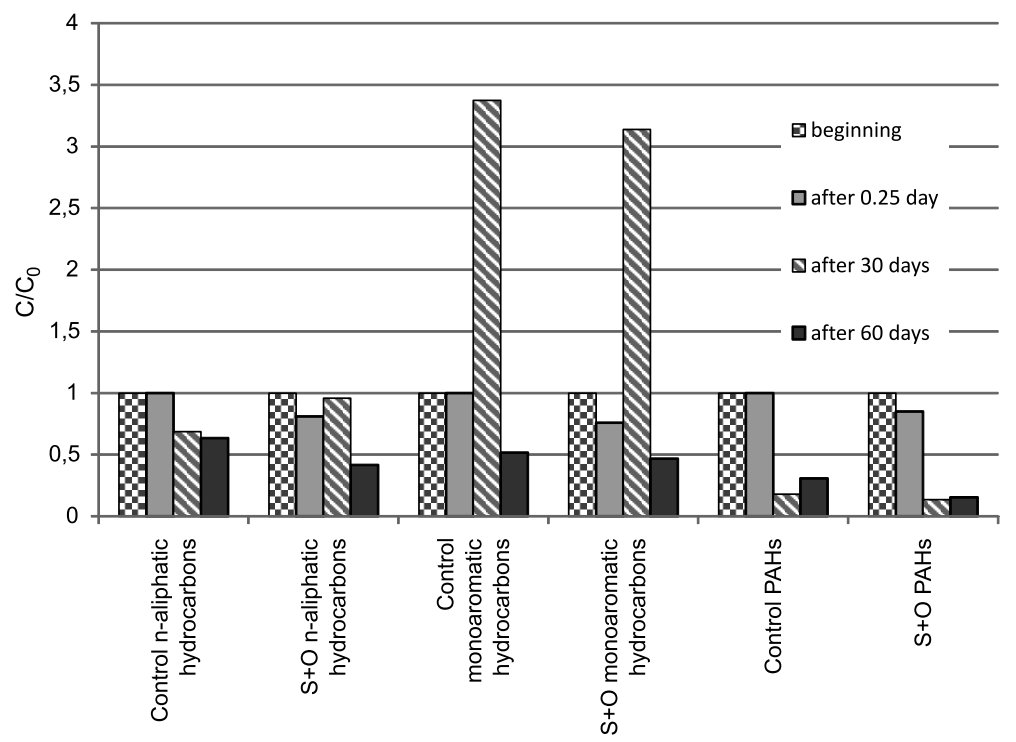

Figure 5. . Relative changes of hydrocarbons content [\%] in comparison to control after 0.25 day, 30 days and 60 days of biodegradation. ( $\mathrm{C}$ - control; $\mathrm{S}+\mathrm{O}$ - soil with $\mathrm{H}_{2} \mathrm{O}_{2}$ )

Table 1. Hydrocarbon content in soil during experiment $\left[\mathrm{mg} \cdot \mathrm{kg}^{-1} \mathrm{~d} . \mathrm{m}.\right]$

\begin{tabular}{|c|c|c|c|c|c|c|c|c|}
\hline Time [days] & \multicolumn{2}{|c|}{0} & \multicolumn{2}{|c|}{$0.25 \mathrm{~d}$} & \multicolumn{2}{|c|}{$30 \mathrm{~d}$} & \multicolumn{2}{|c|}{$60 \mathrm{~d}$} \\
\hline Hydrocarbons & Control & Stimulation & Control & Stimulation & Control & Stimulation & Control & Stimulation \\
\hline \multicolumn{9}{|c|}{ n-Aliphatic } \\
\hline C8 & 58 & 58 & 58 & 32 & 29 & 64 & 16 & 29 \\
\hline C9 & 23 & 23 & 23 & 16 & 12 & 12 & 3 & 2 \\
\hline C10 & 57 & 57 & 57 & 32 & 32 & 48 & 4 & 5 \\
\hline C11 & 157 & 157 & 157 & 130 & 87 & 155 & 6 & 15 \\
\hline C12 & 384 & 384 & 384 & 329 & 205 & 459 & 73 & 71 \\
\hline C13 & 404 & 404 & 404 & 363 & 207 & 393 & 102 & 82 \\
\hline C14 & 584 & 584 & 584 & 480 & 299 & 712 & 73 & 191 \\
\hline C15 & 1021 & 1021 & 1021 & 821 & 513 & 994 & 467 & 302 \\
\hline C16 & 1096 & 1097 & 1097 & 919 & 556 & 1066 & 302 & 434 \\
\hline C17 & 1696 & 1696 & 1696 & 1312 & 856 & 1532 & 1162 & 700 \\
\hline C18 & 1593 & 1593 & 1593 & 1272 & 813 & 1442 & 1157 & 677 \\
\hline C19 & 1124 & 1124 & 1124 & 985 & 564 & 1104 & 862 & 589 \\
\hline $\mathrm{C} 20$ & 899 & 899 & 899 & 932 & 481 & 1008 & 765 & 417 \\
\hline $\mathrm{C} 21$ & 599 & 599 & 599 & 621 & 321 & 673 & 510 & 278 \\
\hline $\mathrm{C} 22$ & 566 & 566 & 566 & 467 & 932 & 559 & 387 & 284 \\
\hline C24 & 1126 & 1126 & 1126 & 625 & 1040 & 1057 & 545 & 361 \\
\hline $\mathrm{C} 26$ & 1574 & 1574 & 1574 & 1258 & 1129 & 1407 & 1085 & 692 \\
\hline $\mathrm{C} 28$ & 1371 & 1371 & 1371 & 1020 & 882 & 1139 & 905 & 556 \\
\hline C30 & 972 & 972 & 972 & 787 & 898 & 797 & 1041 & 531 \\
\hline C32 & 871 & 871 & 871 & 746 & 913 & 911 & 700 & 521 \\
\hline $\mathrm{C} 40$ & 603 & 603 & 603 & 451 & 789 & 576 & 486 & 253 \\
\hline \multicolumn{9}{|c|}{ Monoaromatic } \\
\hline Benzene & 0.6 & 0.6 & 0.57 & 2.4 & 37 & 35 & 4 & 4 \\
\hline Toluene & 1.6 & 1.6 & 1.56 & 0.3 & 0.3 & 0.1 & 0.9 & 0.1 \\
\hline Ethylbenzene & 0.3 & 0.3 & 0.34 & 0.7 & 0.6 & 0.1 & 0.1 & 0.1 \\
\hline $\mathrm{m}+\mathrm{p}$-Xylene & 1.2 & 1.2 & 1.18 & 0.9 & 0.3 & 0.3 & 0.2 & 0.2 \\
\hline o-Xylene & 1.6 & 1.6 & 1.58 & 1.2 & 0.3 & 0.1 & 0.2 & 0.1 \\
\hline Styrene & 1.4 & 1.4 & 1.37 & 0.6 & 0.2 & 0.3 & 0.1 & 0.2 \\
\hline Isopropylbenzene & 5.0 & 5.0 & 4.97 & 2.7 & 0.4 & 0.6 & 0.5 & 0.6 \\
\hline \multicolumn{9}{|c|}{ PAHs } \\
\hline Nap & 24 & 24 & 24 & 24 & 4 & 5 & 4 & 3 \\
\hline Ayl & 14 & 14 & 14 & 13 & 2 & 3 & 3 & 1 \\
\hline Aen & 43 & 43 & 43 & 45 & 5 & 7 & 12 & 3 \\
\hline Flu & 5 & 5 & 5 & 6 & 1 & 1 & 1 & 1 \\
\hline Phe & 10 & 10 & 10 & 12 & 1 & 2 & 3 & 2 \\
\hline Ant & 14 & 14 & 14 & 14 & 2 & 2 & 5 & 3 \\
\hline Fla & 24 & 24 & 24 & 13 & 1 & 1 & 5 & 4 \\
\hline Pur & 1 & 1 & 1 & 1 & 0.5 & 0.1 & 0.6 & 0.2 \\
\hline $\mathrm{BaA}$ & 2 & 2 & 2 & 11 & 5 & 3 & 17 & 0.8 \\
\hline Chr & 12 & 12 & 12 & 8 & 1 & 0.7 & 0.5 & 1.7 \\
\hline $\mathrm{BbF}$ & 16 & 16 & 16 & 7 & 2 & 0.3 & 6 & 0.1 \\
\hline $\mathrm{BkF}$ & 6 & 6 & 6 & 12 & 2 & 1.1 & 1 & 5 \\
\hline $\mathrm{BaP}$ & 5 & 5 & 5 & 4 & 2 & 0.5 & 0.5 & 6 \\
\hline $\mathrm{IcP}$ & 28 & 28 & 28 & 3 & 4 & 0.8 & 1 & 0.5 \\
\hline DhA & 1 & 1 & 1 & 2 & 4 & 0.7 & 2 & 0.5 \\
\hline $\mathrm{BgP}$ & 2 & 2 & 2 & 2 & 0.5 & 0.6 & 0.4 & 0.3 \\
\hline
\end{tabular}


degrade bindings of low bioavailability ${ }^{18,24}$. An indicator expressed by the proportion of grampositive bacteria to gramnegative may reflect the degree of soil contamination with hydrocarbons. According to Margesin et $\mathrm{al}^{25}$ an excessive number of gramnegative bacteria in relation to grampositive $(\mathrm{k}<1)$ is typical for heavily contaminated soil samples. In this context it can be stated, that hydrogen peroxide enhanced biodegradation contributes to contaminants removal from soil.

During the experiment, a decrease of soil reaction was observed which may result from the presence of both intermediate and final products of hydrocarbons biodegradation of acid character. This phenomenon has been also confirmed by studies carried out by other authors ${ }^{\mathbf{8}, 9}$.

Application of biostimulation with hydrogen peroxide resulted in reduction of petrochemicals content in the investigated soil samples. This may be attributed to an increase of bioavailability of hydrocarbon bindings due to oxidation and in consequence increased the activity of the studied microorganisms 4, 7, 16, 26, 27, 28, 29 .

An observed temporary increase of benzo(a)pyrene may be problematic as this compound is considered a cancerogenic factor ${ }^{30,31}$. A rise of the benzo(a)pyrene content may be caused by its desorption from soil pores ${ }^{32}$ or cumulating by Bacillus megaterium strains ${ }^{26,33}$. Elevated contents of some polycyclic compounds may also result from co-metabolism of other compounds ${ }^{34,35}$. Similar results of PAH's decomposition in 40-days experiment were obtained in incubation temperature $30^{\circ} \mathrm{C}^{36}$.

\section{CONCLUSIONS}

Application of hydrogen peroxide in biodegradation processes of petrochemical compounds in soil led to an increase in the number of grampositive bacteria which indicated an effectively progressing degradation of contaminants in soil.

Stimulation of the biodegradation process with hydrogen peroxide increased the effectiveness of n-aliphatic hydrocarbons (C8-C40) degradation by $35 \%$ and PAHs by $50 \%$ compared to control.

Application of hydrogen peroxide to stimulate the process showed no relevant impact on the change of monoaromtic hydrocarbons (BTEX) content compared to control, though a total reduction of their mass observed during the experiment was $50 \%$.

\section{LITERATURE CITED}

1. Kluk, D. (2010). Petroleum substances biodegradeability rate test of drilling waste. Oil and Gas. 1, 27-33 (in Polish)

2. Łebkowska, M., Karwowska, E. \& Miaśkiewicz, E. (1995). Isolation and identification of bacteria from petroleum derivatives contaminated soil. Acta Microbiol. Pol. 44, 3-4, 297-303 3. Łebkowska, M., Zborowska, E., Karwowska, E., Muszynski, A., Tabernacka, A., Naumczyk, J. \& Jeczalik, M. (2011). Bioremediation of soil polluted with fuels by sequential multiple injection of native microorganisms: Field-scale processes in Poland. Ecol. Eng. 37, 11, 1895-1900, DOI: 10.1016/j.ecoleng.2011.06.047.

4. Menendez-Vega, D., Gallego, J.L.R., Pelaez, A.I., Fernandez de Cordoba, G., Moreno, J., Munoz, D. \& Sanchez, J. (2010). Engineered in situ bioremediation of soil and groundwater polluted with weathered hydrocarbons. Eur. J. Soil. Biol. 43, 5-6, 310-321, DOI: 10.1016/j.ejsobi.2007.03.005.
5. Steliga, T. (2008). Optimization of biodegradation process of petroleum pollution in weathered wastes from mud pits. Min. Res. Man. 24 (1/1), 87-112. (in Polish).

6. Guo, H., Yao, J., Cai, M., Qian, Y., Guo, Y., Richnow, H.H., Blake, R.E., Doni, S. \& Ceccanti, B. (2012). Effects of petroleum contamination on soil microbial numbers, metabolic activity and urease activity. Chemosphere 87, 11, 1273-1280 DOI: 10.1016/j.chemosphere.2012.01.034.

7. Steliga, T., Kapusta, P. \& Jakubowicz, P. (2007). Ex situ bioremediation of soil from classic gasworks area polluted with petroleum hydrocarbons. Drilling. Oil. Gas. 24, 1, 475-485. (in Polish).

8. Du, W., Wan, Y., Zhong, N., Fei, J., Zhang, Z., Chen, L. \& Hao, J. (2011). Status quo of soil petroleum contamination and evolution of bioremediation. Pet. Sci. 8, 502-514.

9. Guzik, U., Wojcieszyńska, D., Krysiak, M. \& Kaczorek, E. (2010) Mikrobiological degradation of petroleum alkanes. Oil and Gas. 11, 1019-1027 (in Polish).

10. Kang, N. \& Hua, I. (2005). Enhanced chemical oxidation of aromatic hydrocarbons in soil systems. Chemosphere. 61, 7, 909-22, DOI: 10.1016/j.chemosphere.2005.03.039.

11. Lewkiewicz-Małysa, A. \& Winid, B. (2010). Reduction of hydrocarbon contaminations with the use of chemical methods. Drilling. Oil. Gas. 27, 1-2, 241-249 (in Polish).

12. Watts, RJ., Stanton, PC., Howsawkeng, J. \& Teel, A.L. (2002). Mineralization of a sorbed polycyclic aromatic hydrocarbon in two soils using catalyzed hydrogen peroxide. Water. Res. 36, 17, 4283-4292, DOI: 10.1016/S0043-1354(02)00142-2. 13. Kołwzan, B. (2009). Removal of petroleum products from soil by the prism method. Environ. Poll. Contr. 31, 2, 3-9 (in Polish).

14. Malicka, (1994). Biotechnological cleaning methods of soil contaminated by petroleum compounds and other toxic organics. Gas, Water and Sanit. Engineer. 2, 40-46 (in Polish). 15. Jung, H., Ahn, Y., Choi, H. \& Kim, I.S. (2005). Effects of in-situ ozonation on indigenous microorganisms in diesel contaminated soil: survival and regrowth. Chemosphere. 61, 7, 923-932, DOI: 10.1016/j.chemosphere.2005.03.038.

16. Jung, H., Sohn, K.D., Neppolian, B. \& Choi, H. (2008). Effect of soil organic matter (SOM) and soil texture on the fatality of indigenous microorganisms in intergrated ozonation and biodegradation. J. Hazard. Mater. 11, 150, 3, 809-817, DOI: 10.1016/j.jhazmat.2007.05.032.

17. Robak, M. (2002). Study of acetate utilisation and citrate secretion by Yarrowia lipolytica yeast Yarrowia lipolytica. Sci. J. Wroc. Univ. Food Technology 442, Rozprawy CXCII, 1-91 (in Polish).

18. Huesemann, M.H. \& Truex, M.J. (1996). The role of oxygen diffusion in passive bioremediation of petroleum contaminated soils. J. Hazard. Mater. 51, 1, 93-113, DOI: 10.1016/S03043894(96)01834-1.

19. Barnet, J.A., W. Payne, T.R. \& Yarrow, D. (2000). Yeast characteristics and identification, Third edition, Cambridge University Press.

20. Ciesielczuk, T. \& Kusza, G. (2008). Contamination of flooded soils by polycyclic aromatic hydrocarbons (PAHs). (in) Czamara \& Wiatkowski (eds.) Crisis management-flood protection (practical solutions). Opole Univ. 179-190. (in Polish).

21. Ramus, K. \& Ciesielczuk, T. (2010). Evaluating the efficiency of selected extraction methods for PAHs on the example of compost from urban wastes. Ecol. Chem. Eng. A. 17, 12, $1655-1661$.

22. Wójcikowska-Kapusta, A., Pranagal, J. \& Oleszczuk, P. (2007). Content and migration of polycyclic aromatic hydrocarbons in different soils used. Ecol. Chem. Eng. 14, S2, 233-243. 23. Wilcke, W., Muller, S., Kanchanakool, N., Niamskul, C. \& Zech, W. (1999). Polycyclic aromatic hydrocarbons in hydromorphic soils of the tropical metropolis Bangkok. Geoderma. 91, 297-309. 
24. Lewkiewicz-Małysa, A., Rogowska-Kwas, R. \& Winid, B. (2008). Reduction of environmentally hazardous hydrocabon content. Drilling. Oil. Gas. 2, 2, 453-460 (in Polish).

25. Margesin, R., Hammerle, M. \& Tscherko, D. (2007). Microbial activity and community composition durning bioremediation of diesel-oil-contaminated soil: effects of hydrocarbon concentration, fetilizers and incubation time. Microbial Ecology. 53, 259-269, DOI: 10.1007/s00248-006-9136-7.

26. Kwapisz, E. (2006). Pathways of aerobic petroleum oil hydrocarbons biodegradation. Biotechnologia, 2, 3, 166-188, (in Polish).

27. Nam, K. \& Kukor, J.J. (2000). Combined ozonation and biodegradation for remediation of mixtures of polycyclic aromatic hydrocarbons in soil. Biodegradation. 11, 1-9.

28. Nelson, C.H., Seaman, M., Nelson, S. \& Buschbom, R. (1997). Ozone sparging for the remediation of MGP contaminants. (in): Proceeding of the Fourth Symposium on In Situ and On-Site Bioremediation, New Orleans, LA, USA.

29. Zhang, X., Cheng, S., Zhu, C. \& Sun, S. (2006). Microbial PAH-Degradation in Soil: Degradation Pathways and Contributing Factors. Pedosphere. 16, 5, 555-565, DOI: 10.1016/ S1002-0160(06)60088-X.

30. IARC (1983). Monograps on the Carcinogenic Risk of Chemicals to Humans. Polynuclear Aromatic Compounds. Part 1: Chemical, Envirnomental and Experimental Data. Lyon. 31. Sapota, A. (2002). Polycyclic aromatic hydrocarbons (tar substances dissolved in cyclohexane). Maximum values proposition for particular levels of occupational exposure. Princ. Met. Asses. Walk. Environ. 2, 32, 179-208 (in Polish).

32. Haritash, A.K. \& Kaushik, C.P. (2009). Biodegradation aspects of polycyclic aromatic hydrocarbons (PAHs): a review. J. Hazard. Mater. 169, 1-3, 1-15, DOI: 10.1016/j. jhazmat.2009.03.137.

33. Poglazova, M.N., Fedoseeva, G.E., Khesina, A.I., Meisel, M.N. \& Shabad, L.M. (1967). Further studies on the destruction of benz (a)pyrene by soil bacteria. Dokl. Akad. Nauk SSSR. 11, 176, 5,1165-7 (in Russian).

34. Dean-Ross, D., Moody, J. \& Cerniglia, C.E. (2002). Utilization of mixtures of polycyclic aromatic hydrocarbons by bacteria isolated from contaminated sediment. FEMS Microbiol. Ecol. 41, 1, 1-7, DOI: 10.1111/j.1574-6941.2002.tb00960.x.

35. Stringfellow, W.T. \& Aitken, M.D. (1995). Competitive metabolism of naphthalene, methylnaphthalenes, and fluorene by phenanthrene-degrading pseudomonads. Appl. Environ. Microbiol. 61, 1, 357-362.

36. Yuan, S.Y., Shiung, L.C. \& Chang, B.V. (2002). Biodegradation of polycyclic aromatic hydrocarbons by inoculated microorganisms in soil. Bull. Environ. Contam. Toxicol. 69, 1, 66-73, DOI: 10.1007/s00128-002-0011-z. 